\title{
THE EFFICIENCY OF DECELLULARIZATION OF BOVINE PERICARDIUM BY DIFFERENT CONCENTRATIONS OF SODIUM DODECYL SULFATE
}

\author{
A.A. Sokol ${ }^{1,2^{*}}$, D.A. Grekov ${ }^{1,2}$, G.I. Yemets ${ }^{1}$, A.Yu. Galkin ${ }^{2}$, N.V. Shchotkina ${ }^{1,2}$, \\ A.A. Dovghaliuk ${ }^{1}$, N.M. Rudenko ${ }^{1}$, I.M. Yemets ${ }^{1}$ \\ ${ }^{1}$ Center for Pediatric Cardiology and Cardio Surgery, Kyiv, Ukraine \\ ${ }^{2}$ Igor Sikorsky Kyiv Polytechnic Institute, Kyiv, Ukraine \\ *Corresponding author: cardiotissue@gmail.com \\ Received 23 October 2020; Accepted 10 December 2020
}

\begin{abstract}
Background. In modern cardiovasclar surgery, it is a promising method to use xenotissues, which in their properties are close to human tissues, in order to restore the integrity of the heart chambers, its walls or valves. Decellularization of extracellular matrix (EMC) is applied in the process of creation of such bioprotheses. In EMC, the elastin and collagen components are preserved, and antigenic molecules are eliminated resulting in reduction the risk of rejection. The study is devoted to assessment of the histological, moleculargenetic and cytotoxic properties of decellularized bovine pericardium, processed with various concentrations of trypsin enzyme.
\end{abstract}

Objective. The aim of the work is evaluation of efficiency of bovine pericardial decellularization, based on the use of trypsin enzyme with $1 \%$ Sodium Dodecyl Sulfate (SDS) and 0.1\% SDS.

Methods. Bovine pericardium was used as a biomaterial for decellularization. Decellularization protocol 1 envisages processing of samples with $0.25 \%$ Trypsin solution at $24{ }^{\circ} \mathrm{C}$ with constant shaking $(200 \mathrm{rpm})$ along with processing with $1 \%$ ionic SDS detergent. The samples, prepared according to protocol 2 , were processed with a low concentration of $0.1 \%$ SDS. Histological and morphological properties along with detection of nucleic acids concentration in the samples were studied. Matrix samples were cultured in a human fibroblasts cell culture suspension in order to determine cytotoxicity.

Results. Histological examination has not revealed any presence of cells in tissues, decellularized in accordance with both protocols. More than $99 \%$ of the nucleic acids was removed from decellularized bovine matrix. During our study, we have not observed cytotoxic effect in vitro for protocol 2 matrix samples, decellularized with only $0.1 \%$ SDS. Focal destruction of fibroblasts was observed in conditions of long-term cultivation in protocol 1 samples (Trypsin $+1 \%$ SDS). Cells formed abnormal morphological aggregates. Samples of this group have also demonstated sructural changes in collagen and elastin fibers.

Conclusions. Studies have shown that pericardial matrix tissue, decellularized with low-concentration of $0.1 \%$ SDS, has the same biological properties as the native pericardium. Decellularization of bovine pericardium, using trypsin enzyme with $1 \%$ SDS, has a cytotoxic effect on human cells.

Keywords: pericardium; decellularization; sodium dodecyl sulfate; tissue engineering.

\section{Introduction}

Decellularized extracellular matrix (dECM), extracted from pericardium, has been extensively investigated as a natural scaffold for cardiac tissue engineering applications [1]. dECM is used in cardiac surgery for congenital and acquired heart pathologies to renew heart chambers walls or heart valves integrity $[2,3]$. The bioinplant should be as similar as possible to natural composition of myocardial biopolymers (e.g. collagen, elastin and glycosaminoglycans), mechanically integral and support cardiac cells in vitro. Nowaday dECM of bovine pericardium scaffold is of interest for tissue reconstruction purposes, arising upon implantation of damaged heart [4]. However, there are several issues that need to be solved prior to clinical application of cardiac dECM which includedeveloping of optimal decellularization method, preservation of vasculature and ECM composition, recellularization strategies providing proper reintroduction of cells into specific compartment of the scaffold and prevascularization of thick cardiac dECM [5]. In Center for pediatric cardiology and cardiac surgery we conduct the study aimed at determining the safety and efficacy of different methods of bovine pericardium decellularization. Basing on the scientific investigation results, the most appropriate method of cardiac implant manufacturing was chosen. This method envisages the use of low-concentration Sodium Dodecyl Sulphate (SDS) and Trypsin enzyme. The process has demonstrated the removal 
of cellular components, while effectively preserving integrity of the ECM. The aim of this study was characterised and compared methods for the decellularisation of bovine pericardium, based on the use of low-concentration $0.1 \%$ SDS and Trypsin enzyme with $1 \%$ SDS.

\section{Materials and methods}

\section{Tissue procurement}

The biomaterial, used for decellularization, was bovine pericardium samples from 12-18 month old bovine with intact pericardia. All animals underwent veterinary examination on the base of "Antonivskij myasokombinat, LLC". Aseptic conditions were maintained during collection of biomaterial. The research was performed in accordance with the General Ethical Principles of Animal Experiments (Strasbourg, France, 1985) and Law of Ukraine No. 3447 - IV on Protection of Animals from Cruel Treatment (2006, edited in 2009). The hearts were transported to the lab in cold Hank's solution. Fat and excess tissues were removed from the bovine pericardia and processed within 4 hours upon slaughter, serous layer being separated from the fibrous one. Fatty appendages and excessive connective tissue were removed from the fibrous layer. Pericardium tissue was washed with distilled water $(1000 \mathrm{ml})$, being continuously stirred $(70 \mathrm{rpm})$ for 3 hours at $t=4{ }^{\circ} \mathrm{C}$.

\section{Decellularization protocol for bovine pericardium}

The protocols, developed for decellularization of bovine pericardium, are shown in Table 1. These protocols were used to produce of decellularized bovine pericardium patches $(40 \times 40 \mathrm{~mm})$. In general, the decellularization process took 30 days [6-9].

\section{Histology staining (DAPI and Hematoxylin - Eosin)}

Hematoxylin - Eosin. Histopathological examination of the tissue samples includes fixation in $10 \%$ neutral buffered formalin $(\mathrm{pH} 7.4)$ for at least 3 days at $4{ }^{\circ} \mathrm{C}$. Frozen tissue samples were fixed after snap-freezing and sectioning with a cryostat (thickness of $6 \mu \mathrm{m}$ ).

Validation of cell nuclei removal was performed according to a standard hematoxylin and eosin (H\&E) staining protocol. The stained samples were examined with Olympus BX 51 light microscope.

DAPI. DAPI (4',6-diamidino-2-phenylindole, dihydrochloride) staining was performed directly via incubation of tissue sample (luminal side facing upwards) with $25 \mu \mathrm{g} / \mathrm{mL}$ DAPI, diluted in PBS for $2 \mathrm{~min}$ (in the dark). Achieving the maximum thickness of tissue, adventitia and medium layer were removed via using the approach, suggested by Jelev et al. [10]. ECM was fixed on a plate with forceps under a microscope. Intima layer was carefully removed by stretching it with forceps along with simultaneous cutting on the edges with a scalpel, followed by recovery in PBS. DAPI stains were also applied on paraffin-embedded cross sections $(5 \mu \mathrm{m}$ thickness), following standard protocols for fixation, dehydration, embedding, cutting, deparaffinization, rehydration and staining.

Table 1: Protocols of bovine pericardium decellularization

\begin{tabular}{cccccc}
\hline Protocol & $\begin{array}{c}\text { Osmotic } \\
\text { lysis }\end{array}$ & $\begin{array}{c}\text { Decellularization } \\
\text { conditions }\end{array}$ & Detoxification & $\begin{array}{c}\text { Stabilization } \\
\text { and fixation }\end{array}$ & Cross-linking \\
Protocol \\
of
\end{tabular}




\section{DNA quantification}

DNA was extracted, using the DNA easy Blood and Tissue kit (Qiagen, Germany). 10-25 mg of tissue from both initial materials and decellularized samples were treated with proteinase $\mathrm{K}$ briefly prior to decellularization to quantify the total amount of nucleic acid, ng/mg, in dry tissue and to estimate the percentage of DNA removal after decellularization. Fluorescence measurements (photons per second) were performed at ambient room temperature, $23-24^{\circ} \mathrm{C}$, using a Qubit 3.0 photon counting spectrofluorometer. The detection limit of DNA was $0.2 \mathrm{ng} / \mu \mathrm{g}$ of nucleic acid.

\section{In vitro cytotoxicity testing}

To determine cytotoxicity, Matrix samples were cultured in a human fibroblasts suspension, using preparations of fibroblasts cell culture, transfected with a fluorescent protein of mitochondrial localization. We have cut 3 fragments from each sample with an area of about $8-10 \mathrm{~mm}^{2}$. Cell seeding $(150 \mu \mathrm{l})$ was applied to the standard growth medium (DMEM $+10 \%$ serum) with 30 -minutes impregnation. It should be mentioned, that the number of seeded cells in each fragment was 300 thousand units. Upon that the cells were transferred to the plate and immersed in DMEM $+10 \%$ serum growth medium, culturing under standard conditions of $\mathrm{t} 37^{\circ} \mathrm{C}$ and $5 \% \mathrm{CO}_{2}$ [11-13]. DEM samples were fixed in $10 \%$ buffered formalin, embedded in paraffin, for histological examination. Sections $(5 \mu \mathrm{m})$ were done. Obtained samples were stained with Congo and hematoxylin/eosin (light microscopy) [14-18]. Pictures were made with Olympus BX 51 digital (Tokyo, Japan).

\section{Statistical analysis}

Statistical significance was analyzed, using analysis of variation and $t$-tests as appropriate ones. $p$ value $<0.05$ was regarded as statistically significant. Variation and statistical processing of obtained results were performed with StataIC software.

\section{Results}

In histological sections, made according to protocols 1 and 2 bovine pericardium decelullarization, stained with $\mathrm{H} \& \mathrm{E}$, there was no light microscopic evidence of cells after 14 and 21 days respectively (Fig. 1). There was no obvious difference in the structure of ECM, including distribution of collagen and elastin fibers between cellular bovine tissue and decellularized matrix.

Additionally, the absence of relevant DAPI staining confirmed that most cellular nuclear material was removed after emulsification with SDS detergent. The aforementioned could be clearly visualized by microscopic examination of DAPI samples (Fig. 2). We observed the absence of nuclear elements in both groups.

Concentration of DNA in cellular and decellularized bovine pericardium is shown in Table 2 . There was a significant reduction in DNA content of the decellularized bovine pericardium compared to control samples $(p<0.05)$. The mean percentage of DNA remaining in decellularized bovine pericardium compared to control sample was $0.04 \%$ and $0.22 \%$, being equivalent to $99.9 \%$ and $99.8 \%$ of DNA removal percentage, with protocols 1 and 2 being applied respectively.

Table 2: Comparison of content of DNA in native and decellularized bovine pericardium

\begin{tabular}{ccc}
\hline \multirow{2}{*}{ Group } & $\begin{array}{c}\text { Native bovine } \\
\text { pericardium }\end{array}$ & $\begin{array}{c}\text { Decellularized } \\
\text { bovine pericardium }\end{array}$ \\
\cline { 2 - 3 } & $\begin{array}{c}\text { DNA content per bovine/donor } \\
(\mathrm{ng} / \mathrm{mg})\end{array}$ & Mean, $n=5$ \\
\hline Group 1 & $1436 \pm 116.8$ & $0.5 \pm 0.448$ \\
Group 2 & $1436 \pm 116.8$ & $3.22 \pm 0.664$
\end{tabular}

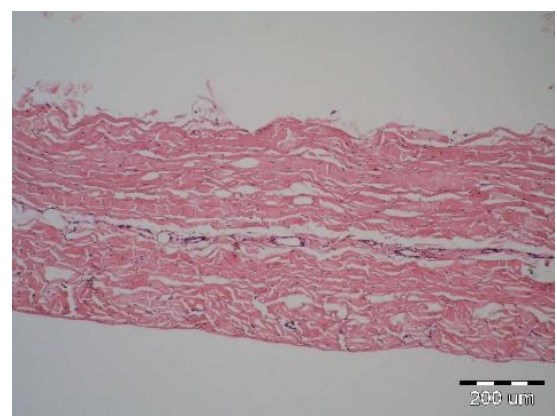

a

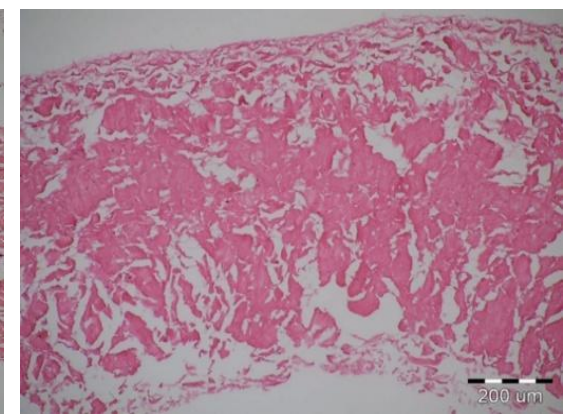

b

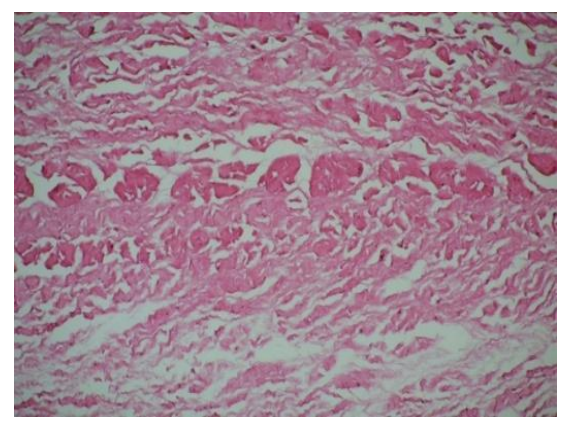

c

Figure 1: Images of histological sections of cellular bovine pericardium and decellularized bovine pericardium. They were stained with Haematoxylin and Eosin, the samples show absence of visible cell nuclei in decellularized bovine pericardium (light microscopy, ×200): (a) Native pericardium; (b) Group 1 (Trypsin enzyme + 1\% SDS); (c) Group 2 (0.1\% SDS) 


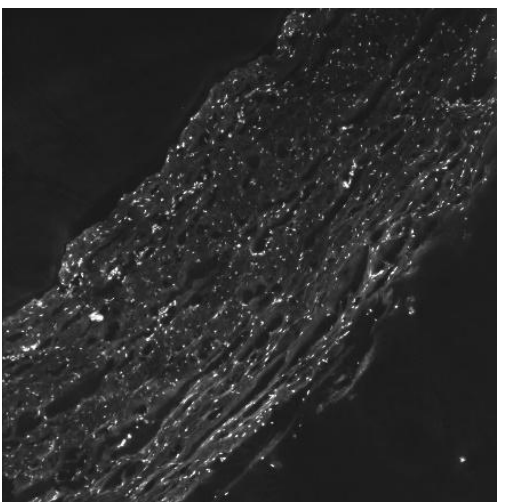

a

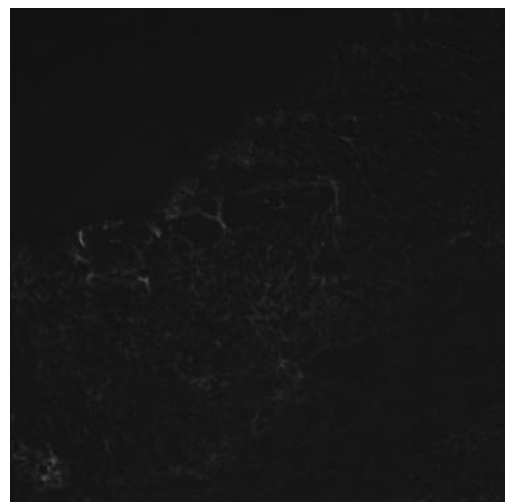

b

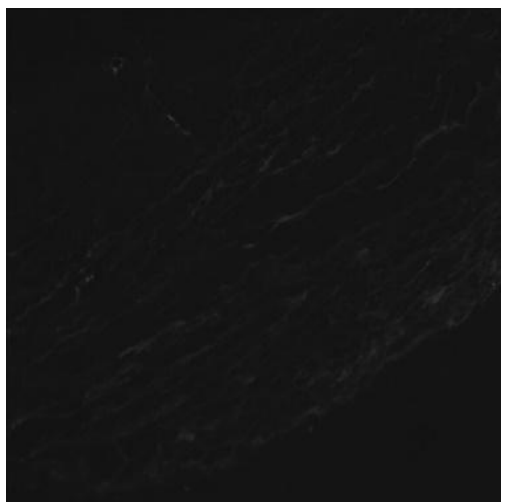

c

Figure 2: Images of histological sections of cellular bovine pericardium and decellularised bovine pericardium. They were stained with DAPI, the samples show absence of visible cell nuclei in decellularised bovine pericardium (fluorescent microscopy, $\times 200$ ): (a) Native pericardium; (b) Group 1 (Trypsin enzyme + 1\% SDS); (c) Group 2 (0.1\% SDS)

In addition, we histologically investigated the cytotoxic effect of dECM for both groups after the first and the second months of cultivation. The microscopy results provided the possibility to to obtain objective information about cytotoxicity levels of the material, location of cells in scaffolds, as well as the condition of connective tissue fibers in samples. Hence, after a month of cultivation we noticed a slight increase of cells in both groups. It should be mentioned, that cells were clearly visible, spindle-shaped, with small visible nuclei, located in long groups, probably oriented to the location of scaffold fibers (Figs. 3, 4). The fibroblasts are often clustered in surface fibers and have enlarged nuclei
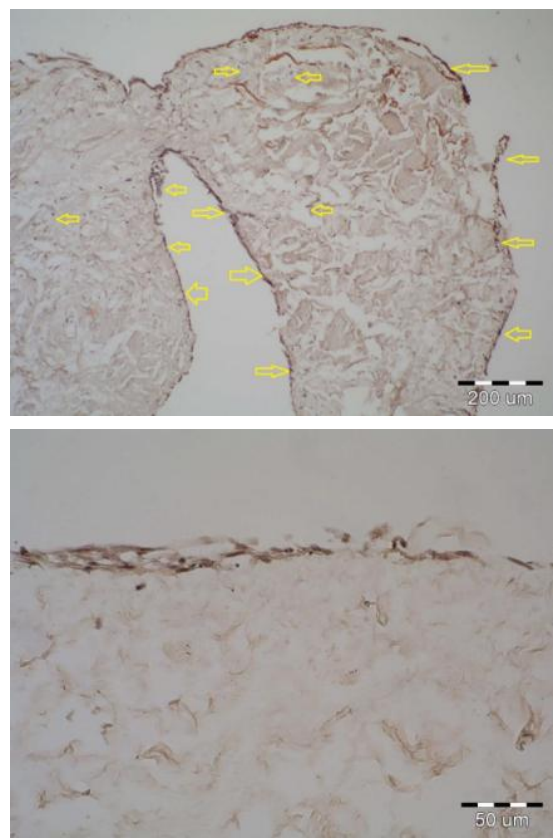

and more rounded shape. Single fibroblasts penetrated the scaffold (depth $150 \mu \mathrm{m}$ ), usually in areas of lower collagen massive density. In general, absence of cell elements in tissue was observed. Collagen and elastin fibers were not altered structurally.

After two months fibroblasts growth on the tissue surfaces in Group 1 showed significant decrease. Fibroblasts had normal morphological form of cells, but cell aggregates were noticed on some parts of scaffold. A focal type of cellular monolayer's destruction was recorded. The predominant number of cells was located in the tissue itself, but single fibroblasts were noticed at a considerable depth of dECM (Fig. 5). At the same time, collagen

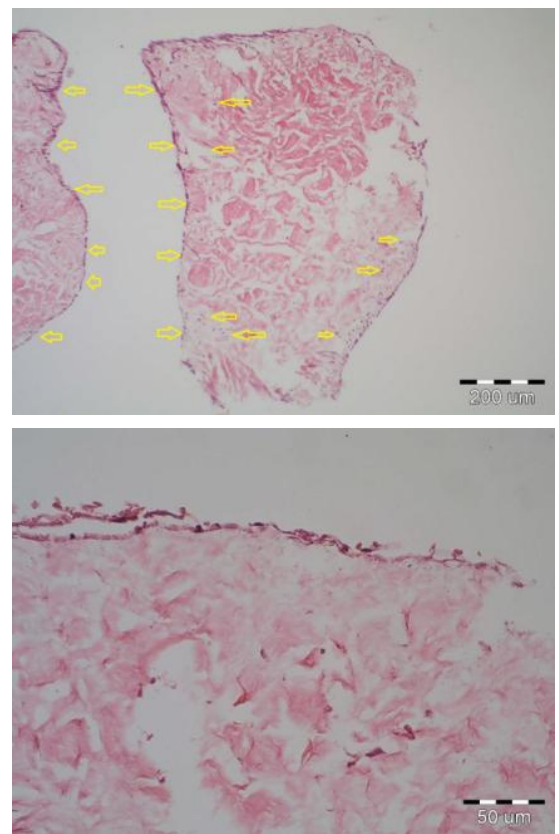

Figure 3: Histological examination of Group 1 (Trypsin $+1 \%$ SDS) samples after 1 month of cultivation (Congo and H/E staining, light microscopy) 

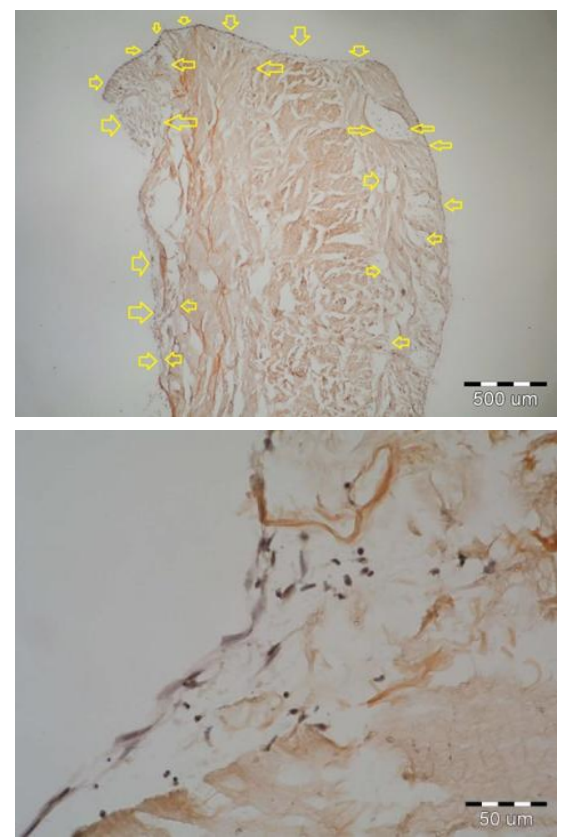

Figure 4: Histological examination of Group 2 samples (0.1\% SDS) after 1 month of cultivation (Congo and H/E staining, light microscopy)
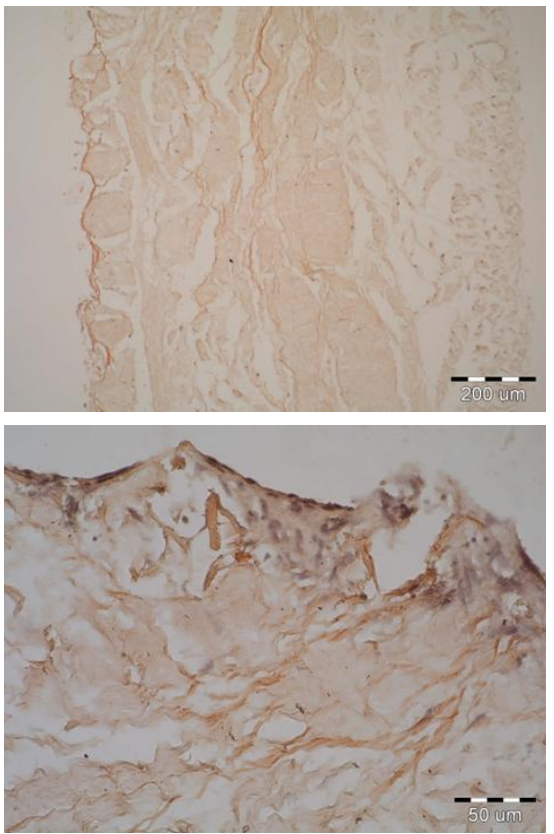

Figure 5: Histological examination Group 1 samples (Trypsin + 1\%) SDS after 2 months of cultivation (Congo and H/E staining, light microscopy)

and elastin components of the matrix were well expressed in the experimental Group $2(0.1 \%$ SDS after two months of cultivation); the fiber bundles were strong and ordered. The majority of cells was placed evenly on the surface of the sample. We observed single fibroblast groups penetrating to a considerable depth up $250 \mu \mathrm{m}$ to $350 \mu \mathrm{m}$ but only in places where the fiber bundles density was
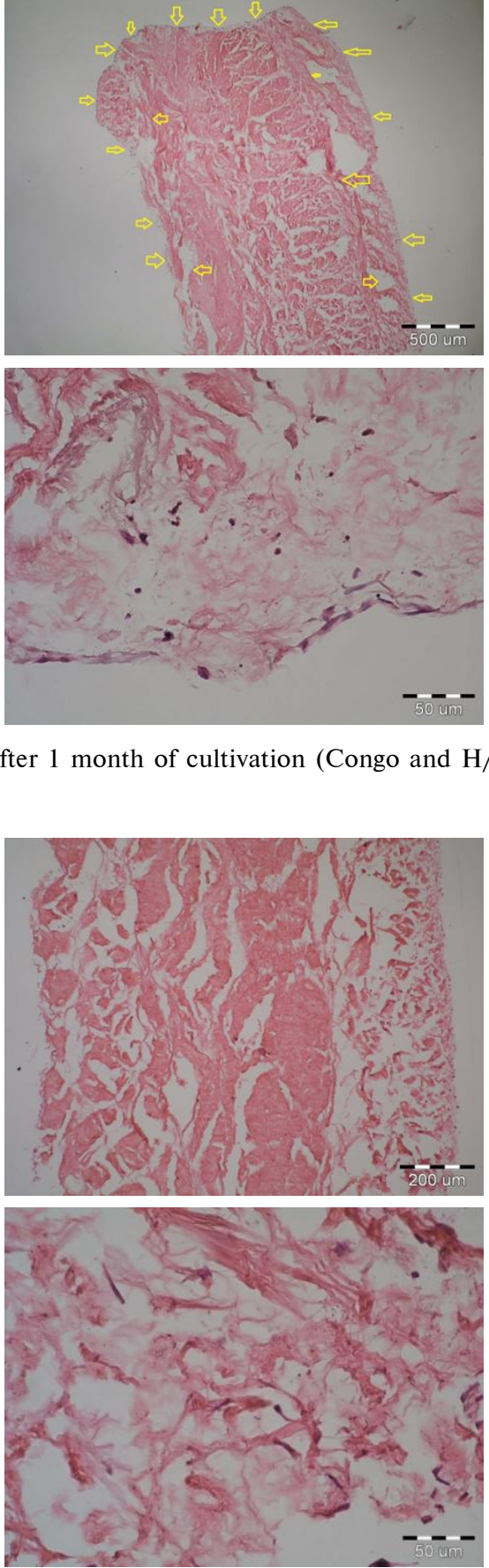

lower (Fig. 6). Cell quantity was higher than in previous microscopy. All cells had normal morphology, spindle-like shape and were associated with collagen and elastin fibers. The fiber morphology was preserved. Thus, in Group 2 we noted the cell growth on the AECM and did not record the death of fibroblasts during two months of cultivation. 

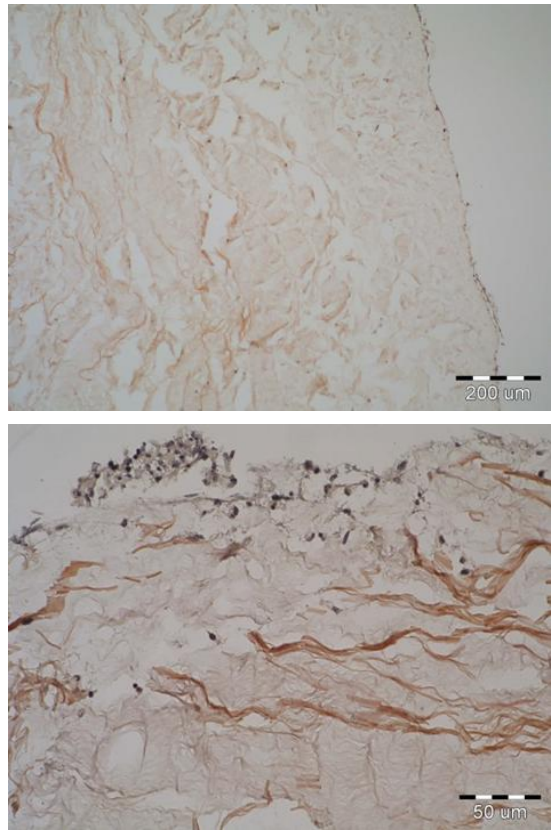
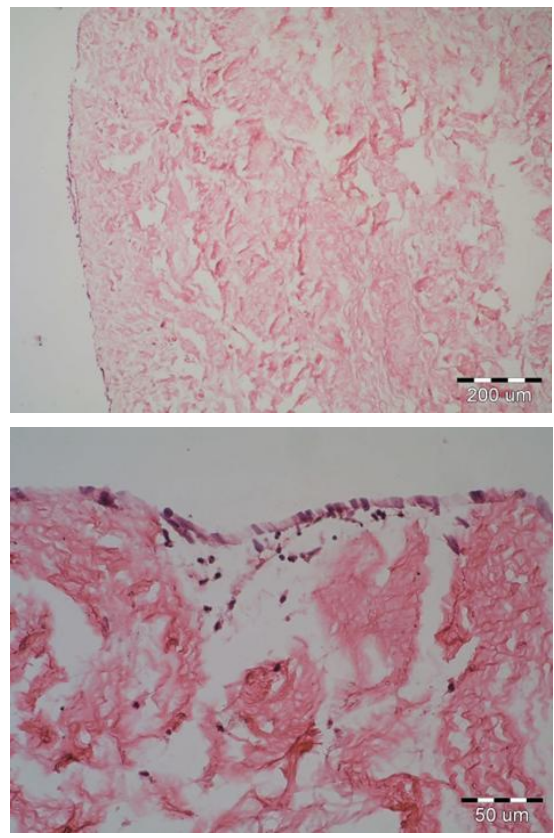

Figure 6: Histological examination of Group 2 samples (0.1\% SDS) after 2 months of cultivation (Congo and H/E staining, light microscopy)

\section{Discussion}

Today, decellularized bovine pericardium being an alternative artificial implant that has a number of problems still can be of certain use [19-23]. Decellularization includes the removal of all cellular components from tissue, while simultaneously preserving the micro- and macroanatomy of the extracellular matrix [24]. dECM should have the same properties as the natural pericardium. Once the process of decellularized bovine pericardium production was established, the study, aimed at characterising the acellular matrix in order to determine whether decellularization process affects biological properties of the native tissue, was conducted. The scientific literature confirms the effective use of ionic detergent SDS for decellularization process. The matrix is purified via solubilization of cytoplasmic and nuclear membranes, denaturation of proteins and removal of nuclear residue [25-27].

This study describes the procedure of bovine pericardium decellularization pericardium, using methods of decellularization that involve Trypsin enzyme with $1 \%$ SDS and low-concentration $0.1 \%$ SDS. It was hypothesised that decellularized bovine pericardium produced via this method would not cause any cytotoxic effect of the human cell. Results of this study support this hypothesis. However, there was considerable variations in cyto- toxic effect, particularly in Group 1, where Trypsin enzyme with $1 \%$ SDS was used.

Presence of cells and their components in $\mathrm{dECM}$ is undesirable in the process of assessment of decellularization quality, as it may cause immunological response, reduce biocompatibility in vitro and promote in vivo reactions with subsequent recellularization. Histological examination of samples, stained with H\&E, showed absence of nuclear elements and preservation of the matrix structure in group 1 and 2. Identification of cellular components, such as DNA, can be used to determine whether cells are still present in biological scaffolds. Histological sections, stained with DAPI, a fluorescent stain that binds to AT regions of DNA, indicated that there was no sign of DNA in decellularized bovine pericardium in both groups.

Complete removal of all cellular components is almost impossible with any method of decellularization [28]. Quantification of residual DNA can be used as an additional marker in determining the efficacy of decellularization process. The DNA assay showed that decellularization, with protocols 1 and 2 been used, managed to remove more than 99\% of nucleic acids from ECM.

Absence of toxic effect of scaffold on the donor's cells is an important part of selection for subsequent transplantation. In this study matrix cytotoxicity was determined via comparison of different microscopy samples in order to identify number 
and location of human fibroblasts, cultured on the obtained sample of tissue. Histological analysis provided the possibility to establish levels of structural changes in scaffold fibers along with the fibroblast cells position after long-term cultivation. In our study we haven't observed any in vitro cytotoxic effect for Group 2 matrix, decellularized with low-concentration $0.1 \%$ SDS during 2 months of cultivation. Although most experiments have studied cytotoxic effect over a short period of time ( 24 to $48 \mathrm{~h}$ ), but long-term investigation are more effective for the following stage of transplantation [25-27, 29].

However, we observed the focal destruction of fibroblasts in matrix under conditions of long-term cultivation in Group 1 (Trypsin $+1 \%$ SDS). In separate areas cells formed into abnormal morphological aggregates. That could be explained by probable processes of fiber resynthesis. We also observed structural changes in collagen and elastin fibers. It is well known that SDS is an ionic detergent, capable of binding collagen fibers, thus removing them and promoting swelling of the tissue, caused by potential break in hydrogen bonds of collagen fibers $[24,30]$. SDS has been reported to interact strongly with the ECM proteins, making their complete removal quite challenging [31]. Taking this fact into account we may assume that we have used a very high concentration of SDS in protocol 1, which led to negative changes in the architectonic of the matrix.

SDS is typically more effective for removing cell residues from tissue compared to other detergents but is also more disruptive to ECM in higher concentrations and exposure time [32]. Thorough residual chemicals removal from ECM after decellularization, particularly detergents such as SDS is important as cytotoxicity is possible and will inhibit or completely negate the beneficial properties of a cell-free ECM scaffold [32, 33]

Our results come with accordance of work [34] where $0.1 \%$ SDS treatment appeared the most efficient. While a single agent decellularization with $2 \%$ SDS was found more efficient among the range of concentrations [35] it was suggested that two reagents might exhibit better decellularization with preservation of the natural tissue structure than single reagent [36]. In addition, low concentrations of SDS were shown to have less matrix disruption on kidney decellularization when little to no damage in renal tubules and vessels and minimal disruption of glomeruli was observed [37]. It was also reported that an increase in SDS concentration leads to faster and increased cell removal, but it can also destroy the ECM microarchitecture [38]. SDS residuals may be highly adherent and cytotoxic (with subsequent detrimental effects on recellularization) so minimization of SDS exposure and concentration it thought to be the relevant approach in decellalurization improvement [39].

\section{Conclusions}

Studies have shown that pericardial tissue, decellularized with low-concentration $0.1 \%$ SDS, has the same biological properties that these of native pericardium. Decellularization of extracellular matrix of bovine pericardium with Trypsin enzyme with $1 \%$ SDS doesn't have cytotoxic effect after 1-month cultivation, but local destruction of fibroblasts after 2 months has been detected, that is the manifestation of cytotoxic effect. The application of ionic detergent SDS in decellularization can cause a cytotoxic effect on the cells on bovine pericardial extracellular matrix scaffold during long-term cultivation if its concentration is higher than $0.1 \%$.

\section{References}

[1] Mallis P, Michalopoulos E, Dimitriou C, Kostomitsopoulos N, Stavropoulos-Giokas C. Histological and biomechanical characterization of decellularized porcine pericardium. Biomed Mater Eng. 2017;28:477-88. DOI: 10.3233/BME-171689

[2] Lima EO, Ferrasi AC, Kaasi A. Decellularization of human pericardium with potential application in regenerative medicine. Arq Bras Cardiol. 2019;113(1):18-9. DOI: 10.5935/abc.20190130

[3] Gonçalves A, Griffiths L, Anthony R, Orton C. Decellularization of bovine pericardium for tissue-engineering by targeted removal of xenoantigens. J Heart Valve Dis. 2005 Mar;14(2):212-7.

[4] Naso F, Gandaglia A. Different approaches to heart valve decellularization: A comprehensive overview of the past 30 years. Xenotransplantation. 2018;25(1):1-10. DOI: 10.1111/xen.12354

[5] Pawan KC, Yi H, Ge Z. Cardiac tissue-derived extracellular matrix scaffolds for myocardial repair: advantages and challenges. Regen Biomater. 2019;6(4):185-99. DOI: 10.1093/rb/rbz017

[6] White LJ, Taylor AJ, Faulk DM, Keane TJ, Saldin LT, Reing JE, et al. The impact of detergents on the tissue decellularization process: a ToF-SIMS study. Acta Biomater. 2017;50:207-19. DOI: 10.1016/j.actbio.2016.12.033 
[7] Ramm R, Goecke T, Theodoridis K, Hoeffler K, Sarikouch S, Findeisen K, et al. Decellularization combined with enzymatic removal of $\mathrm{N}$-linked glycans and residual DNA reduces inflammatory response and improves the performance of porcine xenogeneic pulmonary heart valves in an ovine in vivo model. Xenotransplantation. 2020;27(2):1-12. DOI: 10.1111/xen.12571

[8] Helliwell JA, Thomas DS, Papathanasiou V, Homer-Vanniasinkam S, Desai A, Jennings LM, et al. Development and characterisation of a low-concentration sodium dodecyl sulphate decellularised porcine dermis. J Tissue Eng. 2017;8:1-12. DOI: $10.1177 / 2041731417724011$

[9] Schaner PJ, Martin ND, Tulenko TN, Shapiro IM, Tarola NA, Leichter RF, et al. Decellularized vein as a potential scaffold for vascular tissue engineering. J Vasc Surg. 2004;40(1):146-53. DOI: 10.1016/j.jvs.2004.03.033

[10] Jelev L, Surchev L. A novel simple technique for en face endothelial observations using water-soluble media -'thinned-wall' preparations. J Anat. 2008;212(2):192-7. DOI: 10.1111/j.1469-7580.2007.00844.x

[11] Vunjak-Novakovic G, Freshney RI, editors. Culture of cells for tissue engineering. Wiley; 2006. 536 p.

[12] Blazhevich OV. Cultivation of cells. Minsk: BSU; 2004. 78 p.

[13] Golubev DB, Sominina AA, Medvedeva MN. Guide to the use of cell cultures in virology. Leningrad: Medicine; 1976.224 p.

[14] Roosens A, Somers P, DE Somer F, Carriel V, Van Nooten G, Cornelissen R. Impact of detergent-based decellularization methods on porcine tissues for heart valve engineering. Ann Biomed Eng. 2016 Sep;44:2827-39. DOI: 10.1007/s10439-016-1555-0

[15] Korzhevsky DE. Application of hematoxylin in histological technique. Morphology. 2007;132(6):77-82.

[16] Alturkistani HA, Tashkandi FM, Mohammedsaleh ZM. Histological stains: A literature review and case study. Global J Health Sci. 2016;8(3):72-9. DOI: 10.5539/gjhs.v8n3p72

[17] Horobin RW. Biological staining: mechanisms and theory. Biotech Histochem. 2002;77(1):3-13.

[18] Lilly R. Pathohistological technique and practical histochemistry. Moscow; 1969. 122 p.

[19] Starodubtsev VB, Karpenko AA, Ignatenko PV, Kim IN, Zoloev DG, Gorbatykh VN. Immediate and long-term results of various methods of carotid bifurcation reconstruction. Angiol Sosud Khir. 2014;20(4):93-4.

[20] Mueller C, Dave H, Prêtre R. Surgical repair of aorto-ventricular tunnel. Multimed Man Cardiothorac Surg. 2012;2012:1093-7. DOI: $10.1093 / \mathrm{mmcts} / \mathrm{mms} 006$

[21] Chesnov UM. Biocompatibility of xenopericardium fixed with epoxy compounds in in vitro and in vivo experiments. In: Manak NA, editor. Current issues of cardiology. vol. 2. Minsk: Encyclopedia; 2002. p. 188-90.

[22] Nonaka M, Iwakura A, Yamanaka K. Technique to treat extensive abscesses in double valve replacement for prosthetic valve endocarditis. J Heart Valve Dis. 2013;22(4):575-7.

[23] Akhmedov SD, Afanasyev SA, Dyakova ML, Fatkhutdinov TX, Kaktursky LV. Use of a cell-free matrix for the formation of new blood vessels and heart by tissue engineering. Cell Transplant Tissue Eng. 2009;4(2):32-9.

[24] Gilbert WT, Sellaro LT, Badylak FS. Decellularization of tissues and organs. Biomaterials. 2006;27:3675-83. DOI: 10.1016/j.biomaterials.2006.02.014

[25] Rieder E, Kasimir MT, Silberhumer G, Seebacher G, Wolner E, Simon P, et al. Decellularization protocols of porcine heart valves differ significantly in efficiency of cell removal and susceptibility of the matrix to recellularization with human vascular cells. J Thorac Cardiovasc Surg. 2004;127(2):399-405. DOI: 10.1016/j.jtcvs.2003.06.017

[26] Hudson TW, Zawko S, Deister C, Lundy S, Hu CY, Lee K, et al. Optimized acellular nerve graft is immunologically tolerated and supports regeneration. Tissue Eng. 2004;10(11-12):1641-51. DOI: 10.1089/ten.2004.10.1641

[27] Grauss RW, Hazekamp MG, van Vliet S, Gittenberger-de Groot AC, DeRuiter MC. Decellularization of rat aortic valve allografts reduces leaflet destruction and extracellular matrix remodeling. J Thorac Cardiovasc Surg. 2003 Dec;126(6):2003-10. DOI: $10.1016 / \mathrm{s} 0022-5223(03) 00956-5$

[28] Keane TJ, Swinehart IT, Badylak SF. Methods of tissue decellularization used for preparation of biologic scaffolds and in vivo relevance. Methods. 2015;84:25-34. DOI: 10.1016/j.ymeth.2015.03.005

[29] Tran HLB, Dinh TTH, Nguyen MTN, To QM, Pham ATT. Preparation and characterization of acellular porcine pericardium for cardiovascular surgery. Turk J Biol. 2016;40:1243-50. DOI: 10.3906/biy-1510-44

[30] Oswal D, Korossis S, Mirsadraee S, Wilcox H, Watterson K, Fisher J, et al. Biomechanical characterization of decellularized and cross-liked bovine pericardium. J Heart Valve Dis. 2007;16:165-74.

[31] Andrée B, Bela K, Horvath T, Lux M, Ramm R, Venturini L, et al. Successful re-endothelialization of a perfusable biological vascularized matrix (BioVaM) for the generation of 3D artificial cardiac tissue. Basic Res Cardiol. 2014;109(6):441. DOI: 10.1007/s00395-014-0441-x

[32] Crapo PM, Gilbert TW, Badylak SF. An overview of tissue and whole organ decellularization processes. Biomaterials. 2011;32(12):3233-43. DOI: 10.1016/j.biomaterials.2011.01.057

[33] Schmitt A, Csiki R, Tron A, Saldamli B, Tübel J, Florian K, et al. Optimized protocol for whole organ decellularization. Eur J Med Res. 2017;22:31. DOI: 10.1186/s40001-017-0272-y 
[34] Hashemi SS, Jowkar S, Mahmoodi M, Rafati AR, Mehrabani D, Zarei M, et al. Biochemical methods in production of three-dimensional scaffolds from human skin: A window in aesthetic surgery. World J Plast Surg. 2018;7(2):204-11.

[35] Elder BD, Eleswarapu SV, Athanasiou KA. Extraction techniques for the decellularization of tissue engineered articular cartilage constructs. Biomaterials. 2009;30(22):3749-56. DOI: 10.1016/j.biomaterials.2009.03.050

[36] Xing S, Liu C, Xu B, Chen J, Yin D, Zhang C. Effects of various decellularization methods on histological and biomechanical properties of rabbit tendons. Exp Ther Med. 2014;8(2):628-34. DOI: 10.3892/etm.2014.1742

[37] Caralt M, Uzarski JS, Iacob S, Obergfell KP, Berg N, Bijonowski BM, et al. Optimization and critical evaluation of decellularization strategies to develop renal extracellular matrix scaffolds as biological templates for organ engineering and transplantation. Am J Transplant. 2015;15(1):64-75. DOI: 10.1111/ajt.12999

[38] Manalastas TM, Dugos N, Ramos G, Mondragon JM. Effect of decellularization parameters on the efficient production of kidney bioscaffolds. Appl Biochem Biotechnol. 2020. DOI: 10.1007/s12010-020-03338-2

[39] He M, Callanan A., Lagaras K, Steele JAM, Stevens MM. Optimization of SDS exposure on preservation of ECM characteristics in whole organ decellularization of rat kidneys. J Biomed Mater Res B Appl Biomater. 2017;105(6):1352-60. DOI: $10.1002 / \mathrm{jbm} . b .33668$

А.А. Сокол ${ }^{1,2}$, Д.А. Греков ${ }^{1,2}$, Г.І. Ємець ${ }^{1}$, О.Ю. Галкін ${ }^{2}$, Н.В. Щоткіна ${ }^{1,2}$, А.А. Довгалюк ${ }^{1}$, Н.М. Руденко ${ }^{1}$, І.М. Ємець ${ }^{1}$

${ }^{1}$ ДУ “Науково-практичний медичний центр дитячої кардіології та кардіохірургії МОЗ України”, Київ, Україна

${ }^{2}$ КП ім. Ігоря Сікорського, Київ, Україна

\section{ЕФЕКТИВНІСТЬ ДЕЦЕЛЮЛЯРИЗАЦІї ПЕРИКАРДУ ВЕЛИКОЇ РОГАТОЇ ХУДОБИ РІЗНОЮ КОНЦЕНТРАЦІЄЮ ДОДЕЦИЛСУЛЬФАТУ НАТРІЮ}

Проблематика. В сучасній кардіохірургї̈ для відновлення цілісності камер серця, його стінок або клапанів перспективним $є$ використання ксенотканин, що за своїми властивостями близькі до тканин людини. Для створення таких біопротезів використовують децелюляризований позаклітинний матрикс, у якому зберігаються еластинові та колагенові компоненти, а антигенні молекули елімінуються, що знижує ризик відторгнення. Дослідження присвячене оцінці гістологічних, молекулярно-генетичних та цитотоксичних властивостей децелюляризованого перикарда великої рогатої худоби, обробленого різними концентраціями ферменту трипсину.

Мета. Оцінка ефрективності децелюляризації перикарду великої рогатої худоби, проведеної на основі використання фрерменту трипсину $31 \%$ додецилсульфатом натрію (SDS) та 0,1\% SDS.

Методи реалізації. Матеріалом для дослідження був перикард великої рогатої худоби. Зразки згідно з протоколом децелюляризації 1 були оброблені 0,25\%-ним розчином трипсину за $t=24{ }^{\circ} \mathrm{C}$ при постійному струшуванні (200 об/хв) та $1 \%$-ним іонним детергентом SDS. Зразки, підготовлені за протоколом 2, оброблювали низькою концентрацією 0,1 \%-ного детергенту SDS. Bивчались гістологічні та морфологічні властивості зразків, а також визначались концентрації нуклеїнових кислот у них. Визначення цитотоксичної дії проводили при культивуванні зразків децелюляризованого матриксу в суспензії фрібробластів людини.

Результати. Гістологічне дослідження не виявило наявності клітин у децелюляризованих тканинах за використання обох протоколів. Нуклеїнові кислоти з матриксу було видалено на більш ніж $99 \%$. Під час дослідження ми не спостерігали цитотоксичного ефекту in vitro для зразків матриксу групи 2, децелюляризованого лише 0,1 \% SDS. У зразках групи 1 (трипсин + 1 \% SDS) спостерігалася вогнищева деструкція фібробластів в умовах тривалого культивування. Клітини утворювали аномальні морфологічні агрегати. В цій групі зразків також спостерігались структурні зміни в колагенових та еластинових волокнах.

Висновки. Тканина перикарду, децелюляризована з використанням низької концентрації 0,1 \% SDS, має практично ті ж біологічні властивості, що й нативний перикард. Децелюляризація перикарду великої рогатої худоби за допомогою ферменту трипсину з 1 \% SDS призводить до цитотоксичної дії на клітини людини.

Ключові слова: перикард; децелюляризація; додецилсульфат натрію; тканинна інженерія.

А.А. Сокол ${ }^{1,2}$, Д.А. Греков ${ }^{1,2}$, Г.И. Емец ${ }^{1}$, А.Ю. Галкин ${ }^{2}$, Н.В. Щоткина ${ }^{1,2}$, А.А. Довгалюк ${ }^{1}$, Н.Н. Руденко ${ }^{1}$, И.Н. Емец ${ }^{1}$

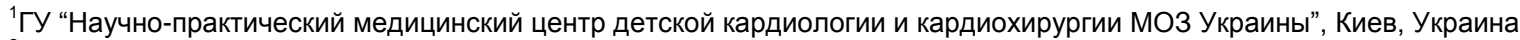

${ }^{2}$ КПИ им. Игоря Сикорского, Киев, Украина

\section{ЭФФЕКТИВНОСТЬ ДЕЦЕЛЛЮЛЯРИЗАЦИИ ПЕРИКАРДА КРУПНОГО РОГАТОГО СКОТА РАЗНЫМИ КОНЦЕНТРАЦИЯМИ ДОДЕЦИЛСУЛЬФАТА НАТРИЯ}

Проблематика. В современной кардиохирургии для восстановления целостности камер сердца, его стенок и клапанов перспективным является использование ксенотканей, которые по своим свойствам близки к тканям человека. Для создания таких биопротезов используют децеллюляризированный внеклеточный матрикс, в котором сохраняются эластиновые и коллагеновые компоненты, а антигенные молекулы элиминируются, чем снижается риск отторжения. Исследование посвящено оценке гистологических, молекулярно-генетических и цитотоксических свойств децеллюляризированного перикарда крупного рогатого скота, обработанного различными концентрациями фермента трипсина.

Цель. Оценка эффективности децеллюляризации перикарда крупного рогатого скота, основанной на применении фермента трипсина с 1 \% додецилсульфата натрия (SDS) и 0,1\% SDS.

Методика реализации. Материалом для исследования служил перикард крупного рогатого скота. Образцы согласно протоколу децеллюляризации 1 были обработаны 0,25\%-ным раствором трипсина при $t=24{ }^{\circ} \mathrm{C}$ при постоянном встряхивании (200 об/мин) и 1 \%-ным ионным детергентом SDS. Образцы, подготовленные по протоколу 2, обрабатывали низкой концентрацией $0,1 \%$-ного детергента SDS. Изучались гистологические и морфологические свойства образцов, а также определялись 
концентрации нуклеиновых кислот в них. Определение цитотоксического действия проводили при культивировании образцов децеллюляризированного матрикса в суспензии фибробластов человека.

Результаты. Гистологическое исследование не выявило наличия клеток в децеллюляризированных тканях при использовании обоих протоколов биотрансформации ткани. Нуклеиновые кислоты из матрикса были удалены более чем на $99 \%$. Во время исследования мы не наблюдали цитотоксического эффекта in vitro для образцов матрикса группы 2, децеллюляризированного $0,1 \%$ SDS. В образцах группы 1 (трипсин + 1 \% SDS) наблюдалась очаговая деструкция фибробластов в условиях длительного культивирования. Клетки образовывали аномальные морфологические агрегаты. В этой группе также наблюдались структурные изменения в коллагеновых и эластиновых волокнах.

Выводы. Ткань перикарда, децеллюлялизированная с использованием низкой концентрацией 0,1 \% SDS, имеет практически те же биологические свойства, что и нативный перикард. Децеллюляризация перикарда крупного рогатого скота с помощью фермента трипсина с 1 \% SDS приводит к цитотоксическому действию на клетки человека.

Ключевые слова: перикард; децеллюляризация; додецилсульфат натрия; тканевая инженерия.

\section{Peer Reviewing Features}

One of the co-authors of the article belongs to the editorial board of this journal.

Therefore, the peer review process was a little bit different from the standard one.

The peer review process was handled by the Deputy Editor-in-Chief, and he did not know who the authors of the article were since the Managing editor removed their names from the manuscript before handing it over to the Deputy Editor-in-Chief. In addition, the subject of the article is not very typical for the mentioned editorial board member, so it would be difficult to determine that he is among the co-authors.

The article was reviewed by two external referees. One of them indicated only minor remarks, and the other one provided feedback with minor and several more significant remarks. The team of authors took into account all the referees' comments and corrected the article. Finally, both referees agreed that the article was improved enough to be published. 